Ekspansi: Jurnal Ekonomi, Keuangan, Perbankan dan Akuntansi

ISSN (Online): 2580-7668 ISSN (Print): 2085-5230

Vol. 11, No. 2 (November 2019), Hal. 157 - 178

\title{
KECURANGAN AKADEMIK PADA MAHASISWA AKUNTANSI BERDASARKAN PERSPEKTIF FRAUD DIAMOND
}

\author{
Adrianus ${ }^{1}$, Billy $^{2}$, Retno Yuliati ${ }^{3}$, Yang Elvy Adelina ${ }^{4}$ \\ ${ }^{1,2,3,4}$ Program Studi Akuntansi, Universitas Prasetiya Mulya, Jakarta, Indonesia \\ Email Korespondensi: billy.wantjik@student.pmsbe.ac.id
}

\begin{abstract}
The purpose of this research is to examine which factors that drive students especially that majoring in accounting, commit academic dishonesty based on fraud diamond theory and refers to (Sabli, Hamid, Haron, $\mathcal{E}$ Wahab, 2018) research. Based on all initial research, we can see that there are many inconsistent results from many universities. The sampling method that we use for this research is purposive sampling using questionnaires. The object of this research is Undergraduate Accounting Student from one of the Public University in Tangerang (XYZ) from the second to the eighth semester (2015-2018 batch), within the total of 260 respondents. Those data samples are processed with Structural Equation Model (SEM). The result of this research shows that only rationalization has positive significant correlation to academic dishonesty. The model of this research is proven to fulfill the goodness-offit, unidimensionality, and reliability standard. The result is adequate to provide input about the importance of maintaining integrity, especially because most of these students will become an accountant in the future.
\end{abstract}

Keywords: Fraud Diamond, Academic Dishonesty, Accounting Student

Abstrak: Penelitian ini bertujuan untuk mengetahui faktor-faktor apa saja yang mendorong mahasiswa khususnya mahasiswa akuntansi melakukan tindak kecurangan akademik berdasarkan teori fraud diamond dengan mengacu pada (Sabli, Hamid, Haron, \& Wahab, 2018). Berdasarkan penelitian terdahulu, terlihat bahwa terdapat inkonsistensi pada hasil riset kecurangan akademik yang terjadi di beberapa universitas dunia. Teknik pengumpulan data dilakukan dengan penyebaran kuesioner dengan responden yaitu mahasiswa aktif Prodi S1 Akuntansi Universitas swasta di Tangerang (disimbolkan XYZ) yang sedang menjalani semester dua hingga delapan (atau mahasiswa angkatan 2015 hingga 2018) sebanyak 260 responden. Data sampel kemudian diolah menggunakan metode Structural Equation Model (SEM). Hasil menunjukkan bahwa hanya rasionalisasi yang memiliki pengaruh positif signifikan terhadap tindakan kecurangan akademik. Atas percobaan pengolahan data, ditemukan hasil goodness-of-fit serta uji unidimensionalitas dan reliabilitas konstruk yang baik, sehingga penelitian berikut diharap mampu memberi masukan bagi Universitas XYZ, terutama prodi Accounting untuk memberikan pembekalan mengenai pentingnya menjaga integritas agar dapat dipercaya oleh pihak lain, terutama karena sebagian besar mahasiswa tersebut akan bekerja sebagai akuntan di kemudian hari.

Kata Kunci: Fraud Diamond, Kecurangan Akademik, Mahasiswa Akuntansi

DOI: 10.35313/ekspansi.v11i2.1346

Riwayat Artikel:

Diterima: 30 - 07 - 2019

Direvisi: 18 - 11 - 2019

Disetujui: 21 - 11 - 2019 


\section{PENDAHULUAN}

Kecurangan akademik merupakan masalah yang umum dalam dunia pendidikan (Davis, Grover, Becker, \& McGregor, 1992). Perilaku tersebut dapat terjadi di berbagai penjuru dunia pendidikan seperti penelitian sebelumnya yang dilakukan di Malaysia (Sabli et al., 2018), Indonesia (Murdiansyah \& Sudarma, 2017), Pakistan (Ellahi, Mushtaq, \& Bashir Khan, 2013), Hong Kong dan Amerika Serikat (Chapman \& Lupton, 2004). Becker, Connolly, Lentz, \& Morrison (2006) sendiri mengklasifikasikan kecurangan akademik dengan cara menyalin dari kertas kecil, kertas, telepon genggam, menyalin dari internet, menggunakan sinyal tangan selama ujian, menyalin pekerjaan rumah milik orang lain, mengutip kalimat milik orang lain tanpa izin atau kutipan, memalsukan dokumen atau catatan akademik, serta membantu siswa lain dalam tindak kecurangan akademik. Sedangkan berdasarkan Buku Panduan Mahasiswa S1 Akuntansi Universitas XYZ, tahun 2015, kecurangan akademik yang melanggar peraturan bagi Universitas sendiri adalah melanggar tata tertib ujian, bekerja sama dengan pihak lain dalam menyelesaikan ujian atau tugas, berusaha mempengaruhi ataupun mengubah evaluasi akademik, grade, atau academic record, secara sengaja merusak pekerjaan akademik dari mahasiswa lain, mengumpulkan tugas akademik yang dikerjakan pihak lain meskipun tugas disyaratkan secara independen, mengumpulkan data yang tidak real sehingga menghasilkan kesimpulan yang menyesatkan, mendapat atau berusaha mendapat beragam materi dengan cara tidak jujur, meminta pihak lain menggantikan mahasiswa mengerjakan ujian ataupun pihak yang menggantikan, dan plagiarisme. Melalui definisi-definisi diatas, tercermin bahwa para mahasiswa rela dan mau melakukan cara apapun untuk menyelesaikan dan memperoleh nilai yang baik pada masa studi mereka, bahkan dilansir dari Republika.co.id, universitas ternama dunia yakni Harvard University pun tidak luput oleh perilaku tersebut.

Penelitian berikut menitik fokuskan pada mahasiswa akuntansi, yang sebagian besar akan melanjutkan jenjang pekerjaan pada profesi akuntan. Seorang akuntan perlu mematuhi prinsip dasar etika agar dapat menjadi Akuntan Profesional yang merupakan penerus informasi. Tidak etis apabila mahasiswa yang akan berperan penting pada keuangan perusahaan sudah terbiasa melakukan perilaku kecurangan akademik sejak masa perkuliahan mereka, sehingga dapat menyebabkan skandal perusahaan di masa depan (Ismail \& Yussof, 2016). Prinsip dasar seorang akuntan terlampir pada Kode Etik Akuntan Profesional oleh Ikatan Akuntansi Indonesia (poin 100.5), yang menyatakan seorang akuntan harus memiliki integritas, objektivitas, kompetensi dan kehati-hatian profesional, kerahasiaan, dan perilaku profesional.

Melalui pentingnya pembentukan karakter mahasiswa akuntansi yang dijelaskan diatas, maka penelitian berikut bermaksud untuk mengkombinasikan teori yang dikemukakan oleh Wolfe \& Hermanson (2004), yaitu Fraud Diamond Theory (FDT) yang merupakan penyempurnaan dari Fraud Triangle Theory (FTT) oleh Cressey di tahun 1953. Fraud Diamond Theory tersebut terdiri atas empat poin yaitu tekanan (pressure), kesempatan atau peluang (opportunity), rasionalisasi (rationalization), dan kemampuan (capability). Mengacu pada teori tersebut, tekanan (pressure) merupakan 
kondisi seseorang yang tertekan sehingga berkomitmen untuk melakukan kecurangan; kesempatan atau peluang (opportunity) merupakan kondisi ditemukannya kelemahan sistem sehingga seseorang dapat melakukan kecurangan dengan mudah; rasionalisasi (rationalization) merupakan pembenaran dan kepercayaan diri seseorang yang menganggap perilaku kecurangan sepantar dengan risiko yang diperoleh; serta kemampuan (capability) merupakan sifat dan kemampuan yang dimiliki seseorang untuk berbuat kecurangan atau telah mengenali peluang khusus dan mengubahnya menjadi kenyataan.

Murdiansyah \& Sudarma (2017) melakukan penelitian terhadap mahasiswa S2 Akuntansi di Universitas Brawijaya, menemukan bahwa tekanan, peluang, rasionalisasi, berpengaruh positif dan signifikan terhadap kecurangan mahasiswa, sedangkan kemampuan memiliki pengaruh negatif signifikan. Namun berbeda dengan penelitian Sabli et al (2018), yang melakukan penelitian kepada mahasiswa akuntansi di Selangor. Hasil penelitian tersebut menunjukkan bahwa kemampuan berpengaruh positif dan signifikan terhadap kecurangan akademik mahasiswa. Sedangkan tekanan, kesempatan, dan rasionalisasi tidak memiliki pengaruh yang signifikan terhadap kecurangan akademik mahasiswa.

Penelitian Nurkhin (2018) pun menunjukkan hasil penelitian yang berbeda. Penelitian dilakukan pada mahasiswa Pendidikan Akuntansi FE UNNES angkatan 2016. Hasil dari penelitian berikut menunjukkan bahwa variabel tekanan dan rasionalisasi memiliki pengaruh positif dan signifikan terhadap kecurangan akademik mahasiswa. Sedangkan variabel kemampuan berpengaruh signifikan negatif dan variabel kesempatan tidak memiliki pengaruh yang signifikan terhadap kecurangan akademik.

Penelitian Budiman (2018), menambahkan konsep gone theory (keserakahan, pengungkapan, dan kebutuhan). Sampel pada penelitian berikut adalah mahasiswa akuntansi di Jawa Tengah. Hasil dari penelitian ini menunjukkan bahwa hanya variabel rasionalisasi dan kemampuan yang berpengaruh positif terhadap kecurangan akademik. Sedangkan variabel pengungkapan memiliki pengaruh negatif terhadap perilaku kecurangan akademik mahasiswa. Namun untuk variabel tekanan, kesempatan, keserakahan, dan kebutuhan tidak memiliki pengaruh terhadap perilaku kecurangan akademik mahasiswa.

Terakhir penelitian oleh Ismail \& Yussof (2016) di Malaysia. Hasil penelitian ini memperlihatkan bahwa, laki-laki memiliki kecenderungan yang lebih besar untuk melakukan kecurangan dalam ujian serta untuk membenarkan kecurangan daripada wanita, hal ini konsisten dengan teori diferensiasi sosial.

Atas hasil-hasil penemuan yang ditemukan sebelumnya, terlihat bahwa adanya inkonsistensi hasil penelitian atas perilaku kecurangan akademik yang terjadi di setiap perguruan tinggi, sehingga penelitian berikut bertujuan untuk mengulik kembali faktor-faktor apa saja yang membuat para mahasiswa melakukan tindakan kecurangan akademik, terutama di Universitas XYZ dengan jurusan Akuntansi. Setelah mengetahui faktor-faktor tersebut, maka diharapkan penelitian berikut dapat memberikan penjelasan mengenai faktor penyebab yang mendorong perilaku 
kecurangan akademik, khususnya di Universitas XYZ sehingga tindak kecurangan dapat diminimalisir pada dunia pendidikan.

\section{TINJAUAN PUSTAKA}

\subsection{Fraud Diamond Theory}

Teori Fraud Diamond merupakan teori yang dikemukakan oleh Wolfe \& Hermanson (2004). Teori tersebut merupakan penyempurnaan dari Fraud Triangle Theory oleh Cressey tahun 1953, yang terdiri atas empat faktor sebagai berikut:

\subsubsection{Tekanan (Pressure/Incentive)}

Menurut Cressey (1953) perilaku kecurangan didorong oleh faktor yang terbagi menjadi tiga, dengan faktor pertama yaitu tekanan. Tekanan tersebut didefinisikan ketika individu memiliki masalah keuangan dan memiliki kesadaran bahwa masalah tersebut hanya dapat diselesaikan dengan melakukan tindakan kecurangan, sehingga Ia melakukan tindakan tersebut. Berdasarkan teori tersebut, maka Wolfe \& Hermanson (2004) mendefinisikan tekanan sebagai tindak kecurangan yang terjadi atas adanya keinginan atau suatu kebutuhan pada individu. Sedangkan pada penelitian Dahiya (2015), tekanan yang terjadi pada mahasiswa disebabkan oleh beberapa faktor yaitu tekanan oleh teman sebaya, lingkungan rumah, lingkungan sekolah, gaya belajar, dan kecemasan akademis.

\subsubsection{Kesempatan (Opportunity)}

Menurut Cressey (1953), faktor kedua perilaku kecurangan yang dapat terjadi adalah karena adanya kesempatan. Berdasarkan pernyataan itu, dapat dikatakan bahwa faktor peluang akan berpengaruh ketika pelaku kecurangan menemukan suatu cara untuk menyelesaikan masalah keuangan dengan menggunakan jabatannya dan adanya kemungkinan bahwa tindakan ini tidak akan ketahuan. Berdasarkan teori tersebut, maka Wolfe \& Hermanson (2004) menyimpulkan bahwa perilaku kecurangan muncul ketika individu yang tepat dapat mengeksploitasi suatu kelemahan pada sistem. oleh individu Azuka (2014) menyatakan peluang dapat muncul secara sengaja atau tidak sengaja dan di luar kendali siswa, seperti ketika mereka telah diberitahu atau tidak sengaja menemukan metode untuk menyontek. Namun seringkali kecurangan akademik muncul ketika siswa menemukan adanya metode tertentu untuk menyontek. Hal ini sangat mudah untuk ditemukan oleh siswa, karena ada banyak sekali cara untuk melakukan kecurangan, namun kurangnya kontrol internal dari sekolah serta rendahnya intervensi dari pengajar merupakan penyebab utama peluang dapat terjadi. 2.1.3 Rasionalisasi (Rationalization)

Menurut Cressey (1953), faktor ketiga yang dapat menyebabkan perilaku kecurangan dapat terjadi adalah karena adanya rasa rasionalisasi. Seringkali pelaku kecurangan mengetahui bahwa hal yang dilakukan adalah ilegal dan salah, namun mereka meyakinkan dirinya untuk beranggapan bahwa hal itu legal. Wolfe \& Hermanson (2004) mengatakan, tindakan kecurangan terjadi atas pembenaran diri dari tindakan tersebut dan hal ini dianggap sebanding dengan risiko yang ada.

McCabe \& Trevino (1996) menyatakan bahwa rasionalisasi yang sering digunakan dalam kecurangan akademik yaitu banyaknya jumlah murid lain yang menyontek, 
murid lainnya yang terbiasa untuk menyontek, dan merasa hukuman yang ada tidak terlalu berat. Penelitian Buckley et al (2018) mengatakan bahwa mahasiswa terbiasa melakukan kecurangan selama kuliah karena mereka merasa sanksi yang diberikan kampus tidak terlalu berat apabila dibandingkan dengan dunia pekerjaan, sehingga adanya pengampunan untuk memperbaiki nilai dianggap sebagai alasan atau rasionalisasi atas tindakannya. Menurut Nonis \& Swift (2001), mahasiswa yang terbiasa merasionalisasikan tindakan yang tidak etis akan lebih condong melakukan kecurangan apabila disandangkan dengan mereka yang mempercayai bahwa tindakan tersebut salah. Hariri, Pradana, \& Rahman (2018) pun menemukan bahwa mahalnya biaya kuliah membuat mahasiswa memiliki hak untuk lulus tepat waktu dan merasa tidak merugikan orang lain merupakan penyebab kecurangan akademik dalam bentuk rasionalisasi.

\subsubsection{Kemampuan (Capability)}

Teori berikut merupakan poin yang menjadi poin tambahan milik Wolfe \& Hermanson (2004), yaitu kemampuan. Kecurangan yang terjadi selama ini dapat terjadi karena seseorang memiliki kemampuan yang tepat untuk membaca situasi. Adanya peluang membuat seseorang tertekan atau ingin melakukan tindakan kecurangan. Kecurangan berikut memang sudah terencana karena pelaku sudah mampu membaca situasi, sehingga terdorong untuk melakukan tindakan yang dapat merugikan orang lain.

Selain itu Wolfe \& Hermanson (2004) menjelaskan faktor kapabilitas yang terbagi atas 6 perilaku pribadi. Pertama adalah positioning, merupakan kondisi ketika seseorang atau fungsi dalam organisasi dapat memberikan kemampuan untuk membuat atau memanfaatkan kesempatan melakukan tindak kecurangan. Tipe kedua adalah intelligence and creativity, yang dapat terjadi ketika seseorang memiliki pemahaman yang cukup dan mampu mengeksploitasi kelemahan pengendalian internal untuk menggunakan posisi, fungsi, atau akses berwenang demi keuntungan yang besar. Ketiga merupakan confidence atau ego, yang dapat terjadi ketika individu memiliki ego yang kuat dan keyakinan besar bahwa tindakannya tidak akan terdeteksi. Tipe keempat adalah coercion, yaitu memaksa orang lain secara persuasif untuk melakukan atau menyembunyikan penipuan. Kelima yaitu deceit, yaitu melakukan kebohongan efektif dan konsisten agar tidak terdeteksi. Terakhir adalah stress, yaitu mengendalikan stres yang muncul setelah melakukan tindak kecurangan dan menutupinya.

Hariri et al., (2018) mengemukakan bahwa mahasiswa mampu melakukan kecurangan akademik karena Ia dapat melakukannya secara hati-hati, tidak merasakan adanya kesulitan, dan dapat melakukan pendekatan kepada dosen sehingga tidak dicurigai akan melakukan tindak kecurangan. Kemampuan menurut Murdiansyah \& Sudarma (2017) adalah berdiskusi dengan kolega, memalsukan absensi serta batas waktu pengumpulan tugas maupun ujian, melakukan copy paste, mengkompilasi hasil pekerjaan teman, dan memplagiasi. 


\subsection{Pengaruh Tekanan terhadap Kecurangan Akademik}

Pada beberapa penelitian yaitu Budiman (2018), Hariri et al., (2018), dan Sabli et al (2018), memiliki hasil yang menunjukkan bahwa tekanan tidak memiliki pengaruh terhadap tindak kecurangan akademik. Sebaliknya Hariyanto, Rini, \& Margianawati (2015) mengemukakan hasil yang menunjukkan adanya pengaruh yang berseberangan dengan konsep fraud diamond. Hasil yang berbanding terbalik adalah adanya pengaruh negatif antara tekanan terhadap tindak kecurangan akademik. Pada penelitian ini pengaruh tekanan terhadap kecurangan akademik di moderasi oleh faktor religiusitas, sehingga hasil dari penelitian ini menunjukkan bahwa semakin tinggi tingkat religiusitas oleh siswa, maka akan memperlemah pengaruh tekanan terhadap perilaku kecurangan akademik.

Becker et al (2006) mengemukakan tekanan merupakan faktor penentu tindak kecurangan akademik. Semakin tinggi tekanan yang dirasakan mahasiswa, maka tindakan kecurangan pun ikut meningkat. Hasil serupa juga dikemukakan oleh Murdiansyah \& Sudarma (2017), dengan faktor-faktor tekanan seperti tuntutan orang tua, tugas yang diberikan terlalu banyak dan sulit, kesibukan di luar kuliah, pengaruh teman, tuntutan lingkungan, dan standar kelulusan yang dianggap berat terbukti memotivasi mahasiswa untuk melakukan tindak kecurangan.

Menurut Muhsin, Kardoyo, \& Nurkhin (2018), tekanan yang dialami mahasiswa sangat mempengaruhi tindakan kecurangan, seperti plagiarisme, pemalsuan data, dan kerja sama yang salah. Pada penelitian ini juga dikatakan bahwa mahasiswa yang memiliki tingkat depresi yang lebih tinggi akan cenderung melakukan tindak kecurangan dibanding yang lebih rendah. Seperti yang disimpulkan oleh Munirah \& Nurkhin (2018), tekanan dapat muncul dari orang terdekat maupun lingkungan sekitar, sehingga apabila tekanan yang dimiliki lebih besar dibandingkan kemampuan yang dimiliki, maka hal ini dapat membuat seseorang mengabaikan nilai-nilai yang dipegang.

Berdasarkan beberapa hasil penelitian tersebut, penulis melihat bahwa adanya kecenderungan dari tindakan kecurangan akademik yang dipengaruhi oleh faktor tekanan. Kecenderungan dari hasil penelitian ini sesuai dengan teori yang dikemukakan oleh Cressey (1953) yaitu tindakan kecurangan dipicu oleh sejumlah faktor, salah satunya tekanan. Berdasarkan penjabaran diatas, maka hipotesis dapat diajukan sebagai berikut:

$\mathrm{H}_{1}$ : Tekanan yang dirasakan mahasiswa berpengaruh positif terhadap perilaku kecurangan akademik mahasiswa.

\subsection{Pengaruh Kesempatan terhadap Kecurangan Akademik}

Sejumlah penelitian tidak berhasil membuktikan pengaruh faktor kesempatan terhadap kecurangan akademik, seperti Budiman (2018) dan Sabli et al., (2018). Hasil menunjukkan kesempatan tidak memiliki pengaruh signfikan terhadap kecurangan akademik. Sebaliknya pada penelitian Hariyanto et al., (2015), yang dimoderasi religiusitas atas pengaruh kesempatan terhadap kecurangan akademik memiliki hasil yang sangat bertolak belakang dengan teori fraud diamond. Penelitian ini menghasilkan hubungan yang negatif antara kedua variabel tersebut. Hubungan 
negatif antara kesempatan dan kecurangan akademik ini menandakan bahwa mahasiswa dengan tingkat religiusitas yang tinggi tidak akan melakukan kecurangan akademik meskipun memiliki peluang yang besar.

Hasil penelitian Becker et al., (2006) menunjukkan bahwa kesempatan merupakan penyebab dari kecurangan akademik. Bentuk dari kesempatan yang ditemukan pada penelitian ini adalah ukuran kelas yang luas dapat menimbulkan kesempatan untuk melakukan kecurangan akademik karena minimnya pengawasan atas area tersebut. Begitu juga dengan kemajuan teknologi yang menimbulkan kesempatan baru untuk melakukan kecurangan, yang disebabkan mahasiswa memiliki pengetahuan akan teknologi yang lebih baru dibandingkan para dosen.

Hasil yang serupa pun ditemui pada penelitian Murdiansyah \& Sudarma (2017). Penelitian ini menjelaskan bahwa kondisi internal control yang lemah, sanksi yang tidak tegas, hadirnya teknologi internet, kondisi kelas, dan koneksi terhadap kakak kelas menjadi faktor-faktor kesempatan yang mendorong mahasiswa untuk melakukan kecurangan akademik. Muhsin et al., (2018) mengemukakan apabila ada kesempatan yang tinggi, maka siswa memiliki kecenderungan yang lebih tinggi pula untuk melakukan kecurangan. Sebaliknya ketika kesempatan relatif rendah, maka siswa tidak akan mencontek. Selain itu Munirah \& Nurkhin, (2018) menyimpulkan bahwa ketika individu merasa mempunyai kondisi maupun situasi yang mendukung untuk melakukan kecurangan dan tidak akan terdeteksi, maka semakin tinggi kesempatan untuk melakukan hal tersebut.

Berdasarkan beberapa hasil penelitian tersebut, penulis melihat terdapat kecenderungan bahwa tindakan kecurangan akademik dipengaruhi oleh faktor kesempatan. Kecenderungan dari hasil penelitian ini sesuai dengan teori yang dikemukakan oleh Cressey (1953) yaitu tindakan kecurangan didorong oleh tiga faktor (fraud triangle) dan salah satunya adalah kesempatan. Berdasarkan penjabaran diatas, maka hipotesis dapat diajukan sebagai berikut:

$\mathrm{H}_{2}$ : Kesempatan yang ditemukan mahasiswa berpengaruh positif terhadap perilaku kecurangan akademik mahasiswa.

\subsection{Pengaruh Rasionalisasi terhadap Kecurangan Akademik}

Penelitian Sabli et al., (2018) tidak dapat membuktikan adanya pengaruh atas faktor rasionalisasi terhadap kecurangan akademik. Hal ini dikarenakan hasil yang ditemukan tidak memiliki pengaruh yang signifikan antara 2 variabel tersebut. Berlawanan dengan teori fraud diamond, Hariyanto et al., (2015) mengungkapkan bahwa faktor rasionalisasi memiliki pengaruh negatif, karena adanya moderasi oleh faktor religiusitas. Kesimpulan dari penelitian ini adalah sifat religi yang tinggi membuat mahasiswa mampu mengurungkan niatnya untuk melakukan tindak kecurangan dan akan berpikir ulang atas akibat dari melakukan tindakan tersebut.

Rasionalisasi mempengaruhi tindak kecurangan akademik mahasiswa (Becker et al., 2006). Sikap dari pihak dosen yang tidak tegas dalam pencegahan tindak kecurangan akademik dapat memicu mahasiswa untuk merasionalisasikan tindak kecurangannya. Selain itu kode etik universitas juga memiliki andil dalam mencegah tindak kecurangan. Apabila kampus tidak memiliki atau tidak mengimplementasikan 
kode etik, maka mahasiswa akan cenderung merasionalkan tindak kecurangan yang dilakukannya.

Menurut Murdiansyah \& Sudarma, (2017), rasionalisasi berpengaruh terhadap tindak kecurangan akademik mahasiswa. Penelitian ini mengemukakan bahwa sifat individu ketika merasa tindakan kecurangan yang dilakukannya merupakan hal yang lumrah karena orang lain juga melakukan hal tersebut, terbiasa untuk melakukan kecurangan akademik, dan merasa tindak kecurangan itu tidak merugikan orang lain adalah bentuk-bentuk rasionalisasi yang menyebabkan perilaku kecurangan akademik. Munirah \& Nurkhin (2018) pun menganggap bahwa tindakan pembenaran atas suatu proses dengan memberikan alasan yang masuk akal dan dapat diterima secara sosial sehingga tidak disalahkan, merupakan bentuk rasionalisasi yang menyebabkan kecurangan akademik.

Atas beberapa hasil penelitian tersebut, penulis melihat adanya kecenderungan bahwa tindakan kecurangan akademik dipengaruhi oleh faktor rasionalisasi. Kecenderungan dari hasil penelitian ini sesuai dengan teori yang dikemukakan oleh Cressey (1953) yaitu tindakan kecurangan didorong oleh tiga faktor (fraud triangle) dan salah satunya adalah rasionalisasi. Berdasarkan penjabaran diatas, maka hipotesis dapat diajukan sebagai berikut:

$\mathrm{H}_{3}$ : Rasionalisasi yang dilakukan mahasiswa berpengaruh positif terhadap perilaku kecurangan akademik mahasiswa.

\subsection{Pengaruh Kemampuan terhadap Kecurangan Akademik}

Penelitian Hariyanto et al., (2015) tidak dapat membuktikan adanya pengaruh kemampuan terhadap kecurangan akademik. Penelitian ini dimoderasi oleh tingkat religiusitas, sehingga hasil yang muncul adalah tidak adanya pengaruh atas kedua variabel tersebut. Sebaliknya penelitian Muhsin et al., (2018) memiliki hasil yang bertolak belakang dengan teori fraud diamond. Penelitian ini mengemukakan bahwa faktor kemampuan memiliki pengaruh negatif terhadap kecurangan akademik, sehingga dapat dikatakan mahasiswa yang memiliki kemampuan lebih rendah cenderung melakukan kecurangan akademik dan semakin tinggi kemampuan yang dimiliki mampu mengurangi perilaku kecurangan akademik. Begitu juga hasil dari penelitian Nurkhin (2018), kemampuan terbukti memiliki pengaruh yang negatif terhadap kecurangan akademik.

Menurut Artani \& Wetra (2017), kemampuan berpengaruh terhadap tindak kecurangan akademik yang dilakukan oleh mahasiswa. Semakin tinggi kemampuan mahasiswa untuk melakukan tindak kecurangan, maka semakin besar pula kecenderungannya untuk melakukan kecurangan tersebut. Penelitian Hariri et al., (2018) menemukan bahwa bentuk kemampuan yang paling mempengaruhi tindak kecurangan adalah sikap yang berhati-hati dan dapat mempengaruhi dosen agar tidak dicurigai ketika melakukan kecurangan. Atas temuan yang serupa, Sabli et al., (2018) menyimpulkan bahwa meskipun adanya tekanan, kesempatan, maupun rasionalisasi namun apabila mahasiswa tersebut tidak memiliki kemampuan yang memadai untuk melakukan kecurangan maka Ia tidak akan melakukannya. 
Atas beberapa hasil penelitian tersebut, penulis melihat adanya kecenderungan bahwa tindakan kecurangan akademik dipengaruhi oleh faktor kemampuan. Kecenderungan dari hasil penelitian ini sesuai dengan teori yang dikemukakan oleh Wolfe dan Hermanson (2004) yaitu tindakan kecurangan didorong oleh empat faktor (fraud diamond) dan salah satunya adalah kemampuan. Berdasarkan penjabaran diatas, maka hipotesis dapat diajukan sebagai berikut:

$\mathrm{H}_{4}$ : Kemampuan yang dimiliki mahasiswa berpengaruh positif terhadap perilaku kecurangan akademik mahasiswa.

\section{METODE PENELITIAN}

\subsection{Data dan Sampel}

Penelitian ini menggunakan data primer. Data primer diperoleh dari jawaban atas penyebaran kuesioner kepada mahasiswa aktif Prodi S1 Akuntansi Universitas XYZ angkatan 2015 sampai dengan 2018. Kuesioner ini terdiri atas tiga bagian pertanyaan. Bagian pertama yaitu identitas responden yang terdiri atas jenis kelamin, angkatan, Indeks Prestasi Kumulatif (IPK), usia, dan suku. Diikuti bagian kedua yaitu frekuensi perilaku kecurangan akademik yang dilakukan pada mahasiswa akuntansi Universitas XYZ, dan bagian ketiga yaitu hubungan antara Fraud Diamond Theory (tekanan, kesempatan, rasionalisasi, dan kemampuan) terkait tindak kecurangan akademik yang dilakukan, sehingga total keseluruhan atas sampel berikut adalah 273 responden. Sebelum disebarkan kepada seluruh mahasiswa aktif S1 Prodi Akuntansi Universitas XYZ, peneliti melakukan pilot test terlebih dahulu kepada 12 mahasiswa yang terdiri dari angkatan 2015, 2016, dan 2017 untuk mengetahui tanggapan dan masukan dari para responden. Setelah menerima seluruh tanggapan dan masukan tersebut, maka terbentuklah kuesioner berikut yang terdiri atas 27 variabel.

\subsection{Analisis Data}

Penelitian berikut akan melakukan uji hipotesis dengan menggunakan metode Model Persamaan Struktural atau Structural Equation Modeling (SEM). Structural Equation Modeling (SEM) sendiri merupakan gabungan dari dua metode statistik yang terpisah yaitu analisis faktor (factor analysis) yang dikembangkan di ilmu psikologi dan psikometri serta model persamaan simultan (simultaneous equation modeling) yang dikembangkan di ekonometrika (Ghozali, 2014).

Teknik analisis data yang dilakukan yaitu statistik deskriptif dengan melihat pada demografi responden seperti terlampir pada kuesioner penelitian, yaitu jenis kelamin, angkatan, IPK, usia, suku, dan jumlah saudara pada responden.

\subsection{Model Penelitian}

Penelitian berikut terdiri atas satu variabel laten dengan 22 variabel teramati. Variabel laten dapat dibedakan menjadi dua, yaitu variabel endogen dan variabel eksogen (Ghozali, 2014). Variabel endogen adalah variabel dependen yang dipengaruhi oleh variabel independen (eksogen), yang pada penelitian berikut merupakan kecurangan akademik (academic dishonesty) dengan mengacu pada Becker_et al (2006). Sedangkan variabel eksogen adalah variabel independen yang mempengaruhi variabel dependen, yang pada penelitian berikut merupakan tekanan (pressure), kesempatan 
(opportunity), rasionalisasi (rationalization), dan kemampuan (capability) dengan mengacu pada Becker et al (2006); Hariri et al (2018); Murdiansyah \& Sudarma (2017); Sabli et al (2018); dan Wolfe \& Hermanson (2004).

Kuesioner bagian pertama merupakan identitas responden, dan kuesioner bagian kedua merupakan indikator atas "Kecurangan akademik" yang digunakan untuk mengukur frekuensi perilaku kecurangan akademik yang dilakukan oleh mahasiswa akuntansi Universitas XYZ, dengan lima item variabel teramati yang mewakili pernyataan seperti "menyalin dan/atau parafrase pekerjaan orang lain dan diakui sebagai pekerjaan sendiri”. Skala yang digunakan adalah lima skala likert, dengan poin satu yang berarti "tidak pernah" hingga lima yang berarti "selalu”.

Kuesioner bagian ketiga merupakan indikator atas "Teori Fraud Diamond" yang digunakan untuk mengetahui faktor-faktor pendorong mahasiswa untuk melakukan tindakan kecurangan akademik. Terdapat 17 item variabel teramati yang mewakili pertanyaan atas dasar tekanan, kesempatan, rasionalisasi, dan kemampuan. Skala yang digunakan adalah lima skala likert, dengan poin 1 yang berarti "tidak setuju" hingga 5 yang berarti "sangat setuju".

Berdasarkan penjelasan diatas, maka dapat dibentuk kerangka penelitian sebagai berikut:

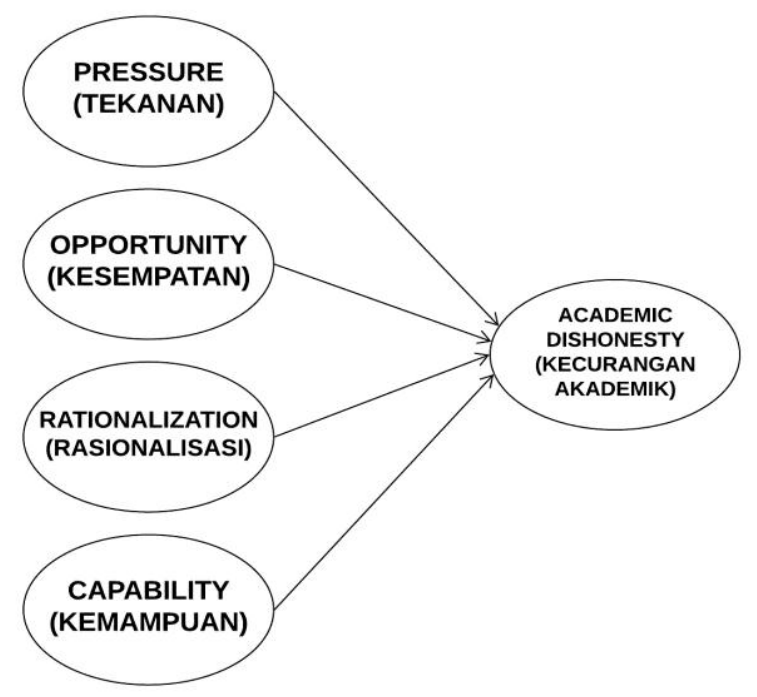

Gambar 1. Model Penelitian

Sumber: diadopsi dari model Fraud Diamond theory(Wolfe \& Hermanson, 2004)

\subsection{Operasionalisasi Variabel}

Berikut merupakan variabel yang menjadi pertanyaan kuesioner pada penelitian berikut:

Tabel 1. Variabel dan Indikator terkait Model Penelitian

\begin{tabular}{|l|l|l|}
\hline \multicolumn{3}{|c|}{ VARIABEL ENDOGEN } \\
\hline \multicolumn{1}{|c|}{ Variabel } & \multicolumn{1}{c|}{ Indikator } & Sumber \\
\hline $\begin{array}{l}\text { Kecurangan } \\
\text { Akademik (KA) }\end{array}$ & $\begin{array}{l}\text { 1. Menyalin pekerjaan orang lain dan diakui sebagai } \\
\text { pekerjaan sendiri (KA1) }\end{array}$ & \\
\hline
\end{tabular}




\begin{tabular}{|c|c|c|}
\hline \multicolumn{2}{|c|}{ VARIABEL ENDOGEN } \\
\hline Variabel & \multicolumn{1}{|c|}{ Indikator } & \multicolumn{1}{|c|}{ Sumber } \\
\hline \multirow{4}{*}{} & $\begin{array}{l}\text { 2. Melakukan segala cara untuk memperoleh soal tes, } \\
\text { sebelum tes berlangsung (meminta kelas sebelumnya) } \\
\text { (KA2) }\end{array}$ & $\begin{array}{c}\text { (Becker et al., } \\
\text { 2006) }\end{array}$ \\
\cline { 2 - 2 } & $\begin{array}{c}\text { 3. Mengutip beberapa kalimat dari seorang penulis tanpa } \\
\text { mencantumkannya di tugas yang dikerjakan (KA3) }\end{array}$ & \\
\cline { 2 - 3 } & 4. Memberikan jawaban kepada orang lain saat tes (KA4) & \\
\cline { 2 - 3 } & 5. Menyontek saat tes dalam bentuk apapun (KA5) & \\
\hline
\end{tabular}

\begin{tabular}{|c|c|c|}
\hline \multicolumn{3}{|c|}{ VARIABEL EKSOGEN } \\
\hline Variabel & Indikator & Sumber \\
\hline \multirow[t]{6}{*}{ Tekanan $(\mathrm{T})$} & $\begin{array}{l}\text { 1. Banyaknya kegiatan diluar perkuliahan (kepanitiaan, } \\
\text { kompetisi, dan lain-lain) (T1) }\end{array}$ & \multirow[t]{4}{*}{$\begin{array}{l}\text { (Murdiansyah \& } \\
\text { Sudarma, 2017) }\end{array}$} \\
\hline & $\begin{array}{l}\text { 2. Takut kehilangan bantuan keuangan (Mis: orang tua } \\
\text { enggan membiayai mata kuliah yang harus diulang) } \\
\text { (T2) }\end{array}$ & \\
\hline & $\begin{array}{l}\text { 3. Ekspektasi orang tua atau keluarga untuk } \\
\text { mendapatkan nilai yang tinggi (T3) }\end{array}$ & \\
\hline & 4. Menghindari rasa malu atas nilai yang rendah (T4) & \\
\hline & $\begin{array}{l}\text { 5. Rasa tidak senang jika nilainya dibandingkan dengan } \\
\text { orang lain (T5) }\end{array}$ & \multirow[t]{2}{*}{ (Sabli et al., 2018) } \\
\hline & 6. Banyaknya tugas yang diberikan oleh dosen (T6) & \\
\hline \multirow[t]{5}{*}{ Kesempatan (KES) } & 1. Sistem tes dilakukan secara online (KES1) & \multirow[t]{2}{*}{ (Sabli et al., 2018) } \\
\hline & 2. Lemahnya pengawasan selama ujian (KES2) & \\
\hline & $\begin{array}{l}\text { 3. Dosen jarang menyadari adanya tindak kecurangan } \\
\text { (KES3) }\end{array}$ & $\begin{array}{l}\text { (Munirah \& } \\
\text { Nurkhin, 2018) }\end{array}$ \\
\hline & $\begin{array}{l}\text { 4. Kondisi kelas yang dapat mempermudah untuk } \\
\text { melakukan kecurangan (Mis: ramai, posisi duduk, } \\
\text { dll) (KES4) }\end{array}$ & (Budiman, 2018) \\
\hline & $\begin{array}{l}\text { 5. Sanksi yang diberikan oleh kampus kurang } \\
\text { memberikan efek jera (KES5) }\end{array}$ & $\begin{array}{l}\text { (Murdiansyah \& } \\
\text { Sudarma, 2017) }\end{array}$ \\
\hline \multirow[t]{5}{*}{ Rasionalisasi (R) } & 1. Berambisi untuk memperoleh nilai yang tinggi (R1) & \multirow{5}{*}{$\begin{array}{l}\text { (Becker et al., } \\
\text { 2006) }\end{array}$} \\
\hline & $\begin{array}{l}\text { 2. Merasa kecurangan yang dilakukan tidak merugikan } \\
\text { orang lain (R2) }\end{array}$ & \\
\hline & $\begin{array}{l}\text { 3. Merasa kecurangan yang dilakukan adalah hal yang } \\
\text { biasa dilakukan (R3) }\end{array}$ & \\
\hline & 4. Banyak mahasiswa yang mencontek saat tes (R4) & \\
\hline & $\begin{array}{l}\text { 5. Tindak kecurangan akademik sering terjadi di } \\
\text { kampus (R5) }\end{array}$ & \\
\hline \multirow[t]{4}{*}{$\begin{array}{l}\text { Kemampuan } \\
\text { (KEM) }\end{array}$} & $\begin{array}{l}\text { 1. Positioning }=\text { Memanfaatkan kesempatan untuk } \\
\text { melakukan tindakan kecurangan akademik (KEM1) }\end{array}$ & \multirow[t]{4}{*}{$\begin{array}{lr}\text { (Wolfe } \quad \& \\
\text { Hermanson, 2004) }\end{array}$} \\
\hline & $\begin{array}{l}\text { 2. Intelligent }=\text { Mampu memikirkan strategi khusus } \\
\text { untuk melakukan tindakan kecurangan akademik } \\
\text { (KEM2) }\end{array}$ & \\
\hline & $\begin{array}{l}\text { 3. Eg / confidence = Merasa sangat yakin bahwa tindakan } \\
\text { kecurangan akademik tidak dapat dideteksi (KEM3) }\end{array}$ & \\
\hline & $\begin{array}{l}\text { 4. Coercion = Mampu meyakinkan orang lain untuk tidak } \\
\text { melaporkan tindakan kecurangan akademik (KEM4) }\end{array}$ & \\
\hline
\end{tabular}




\begin{tabular}{|l|l|c|}
\hline \multicolumn{3}{|c|}{ VARIABEL EKSOGEN } \\
\hline Variabel & \multicolumn{1}{|c|}{ Indikator } & Sumber \\
\hline & $\begin{array}{l}\text { 5. Deceit = Mampu membuat berbagai alasan untuk } \\
\text { menutupi kecurangan akademik (KEM5) }\end{array}$ & \\
\cline { 2 - 2 } & $\begin{array}{l}\text { 6. Stress = Mampu menekan rasa bersalah setelah } \\
\text { melakukan tindakan kecurangan akademik (KEM6) }\end{array}$ & \\
\hline
\end{tabular}

\section{HASIL DAN PEMBAHASAN}

\subsection{Statistik Deskriptif}

Penelitian berikut mengkaji beberapa data demografis dari responden pada saat proses pengumpulan data. Tabel 1 menunjukkan profil demografis responden yang terkumpul dengan jumlah responden sebanyak 260 dari total 273 responden, maka ditunjukkan bahwa kuesioner yang terkumpul adalah sebesar 95,24\%. Kekurangan atas jumlah responden tersebut terdiri atas enam orang yang tidak melanjutkan studinya kembali di Universitas XYZ, sedangkan tujuh orang lainnya memang tidak mengisi kuesioner penelitian. Sebanyak 30,00\% dari jumlah merupakan responden dengan jenis kelamin laki-laki, dan 70,00\% dari total keseluruhan merupakan responden dengan jenis kelamin perempuan. Dari keempat angkatan, jumlah angkatan paling banyak berasal dari angkatan 2018 dengan jumlah responden sebanyak 33,85\%, dan paling sedikit berasal dari angkatan 2017 dengan jumlah 18,46\%. Seluruh mahasiswa akuntansi angkatan 2017 pun telah sepenuhnya mengisi kuesioner berikut dengan jumlah 48 mahasiswa. Dilihat melalui rentang IPK, sebesar 48,85\% memiliki IPK diatas 3,25 sedangkan persentase terendah dengan rentang IPK $1,75<$ IPK $\leq 2,25$ dengan jumlah hanya 2,69\%. Dari 260 responden, rata-rata terbesar umur responden adalah 19 tahun sebesar 26,54\%, sedangkan umur 17 dan 23 tahun hanyalah 0,38\% karena hanya terwakilkan satu orang saja. Sedangkan untuk suku, rata-rata terbesar suku mahasiswa accounting Universitas XYZ adalah Tionghoa dengan persentase 75,38\% atau terwakilkan oleh 196 orang, yang kemudian diikuti suku Jawa (14,23\%), Sunda (2,69\%), Batak (2,31\%), Minangkabau (1,54\%), dan Lainnya (3,46\%).

Tabel 2. Statistik Deskriptif

\begin{tabular}{|l|l|l|l|}
\hline & Item & Total & Percetage \\
\hline \multirow{3}{*}{ Jenis Kelamin } & Laki-laki & 78 & $30,00 \%$ \\
\cline { 2 - 4 } & Perempuan & 182 & $70,00 \%$ \\
\hline \multirow{4}{*}{ Angkatan } & 2015 & 58 & $22,31 \%$ \\
\cline { 2 - 4 } & 2016 & 56 & $21,54 \%$ \\
\cline { 2 - 4 } & 2017 & 48 & $18,46 \%$ \\
\cline { 2 - 4 } & 2018 & 88 & $33,85 \%$ \\
\hline \multirow{4}{*}{ IPK } & IPK $>3.25$ & 127 & $48,85 \%$ \\
\cline { 2 - 4 } & $2,75<\mathrm{IPK} \leq 3,25$ & 95 & $36,54 \%$ \\
\cline { 2 - 4 } & $2,25<\mathrm{IPK} \leq 2,75$ & 31 & $11,92 \%$ \\
\cline { 2 - 4 } & $1,75<\mathrm{IPK} \leq 2,25$ & 7 & $2,690 \%$ \\
\hline \multirow{4}{*}{ Usia } & 23 tahun & 1 & $0,380 \%$ \\
\cline { 2 - 4 } & 22 tahun & 41 & $21,92 \%$ \\
\cline { 2 - 4 } & 21 tahun & 57 & $15,77 \%$ \\
\cline { 2 - 4 } & 20 tahun & 41 & $26,54 \%$ \\
\cline { 2 - 4 } & 19 tahun & 69 & \\
\hline
\end{tabular}




\begin{tabular}{|l|l|l|l|}
\hline & Item & Total & Percetage \\
\hline \multirow{4}{*}{ Suku } & 18 tahun & 50 & $19,23 \%$ \\
\cline { 2 - 4 } & 17 tahun & 1 & $0,380 \%$ \\
\hline \multirow{5}{*}{} & Tionghoa & 196 & $75,38 \%$ \\
\cline { 2 - 4 } & Jawa & 37 & $14,23 \%$ \\
\cline { 2 - 4 } & Sunda & 7 & $2,690 \%$ \\
\cline { 2 - 4 } & Batak & 6 & $2,310 \%$ \\
\cline { 2 - 4 } & Minangkabau & 4 & $1,540 \%$ \\
\cline { 2 - 4 } & Lainnya & 9 & $3,460 \%$ \\
\hline
\end{tabular}

\section{Sumber: data yang diolah}

\subsection{Penilaian Model Pengukuran}

Pengujian hipotesis atas penelitian berikut menggunakan metode Structural Equation Model (SEM), dengan menggunakan program AMOS versi 24. Dengan menggunakan 27 variabel, data tersebut kemudian diolah namun ternyata hasil goodness-of-fit dan validitas serta reliabilitas yang belum menunjukkan angka dengan rata-rata good fit dan reliabel, sehingga harus disesuaikan beberapa variabel yang dihapuskan untuk mencapai keterangan angka yang baik. Tahapan pertama dengan melakukan penghapusan sebanyak sembilan variabel yang terdiri atas T1, T2, T6, KES1, KES5, R1, KA1, KA2, dan KA3. Kesembilan variabel tersebut dihapuskan karena menyajikan angka standard loading yang kurang dari 0,50 (Ghozali, 2014). Karena belum menyajikan angka kecocokan model dengan rata-rata yang baik, maka kembali dilakukan penyesuaian sebanyak lima variabel yang dihapuskan yakni T3, KES2, R3, KEM1, dan KEM2 karena menyajikan angka standardized residual covariances yang melebihi dua. Bagozzi dan Yi (1988) mengungkapkan bahwa angka standardized residual covariances atau normalized residuals dengan angka model yang benar adalah angka dengan rata-rata kurang dari dua. Namun ternyata masih terdapat angka reliabilitas yang belum baik, sehingga langkah terakhir dengan menghubungkan kovarian pada mode "Modification Indices". Pemilihan jatuh kepada angka yang besar yakni e21 〈-> Rasionalisasi sebesar 6,147 dan e7 〈-> e27 sebesar 14,140, yang selaras dengan Arbuckle (2006) bahwa harus dilakukan korelasi modification indices dengan angka index yang besar. Setelah menghapuskan 14 variabel dan menghubungkan dengan kovarian, maka hasil mengindikasikan kecocokan model yang cukup baik, dengan melihat nilai Chi-Square, RMSEA, GFI, CMIN/DF, AGFI, TLI, NFI, PGFI, dan PNFI dengan keterangan good fit. Hasil Goodness of Fit dapat dilihat secara detail melalui Tabel 3.

Tabel 3. Goodness of Fit Keseluruhan Model

\begin{tabular}{|l|l|l|l|}
\hline \multicolumn{1}{|c|}{ Goodness of Index } & \multicolumn{1}{|c|}{ Cut-Off Value } & Hasil Model & \multicolumn{1}{c|}{ Keterangan } \\
\hline Chi-square & Diharapkan kecil, dengan $\mathrm{p} \geq 0,05$ & 0,102 & Good Fit \\
\hline RMSEA & $\leq 0,08$ & 0,031 & GoodFit \\
\hline GFI & $0-1($ direkomendasikan $>0,90)$ & 0,964 & Good Fit \\
\hline CMIN/DF & $<5($ direkomendasikan $<2)$ & 1,250 & Good Fit \\
\hline AGFI & $0-1($ direkomendasikan $>0,90)$ & 0,939 & Good Fit \\
\hline TLI & $0-1($ direkomendasikan $>0,90)$ & 0,983 & Good Fit \\
\hline NFI & $0-1($ direkomendasikan $>0,90)$ & 0,945 & Good Fit \\
\hline PGFI & $0-1$ & 0,572 & Good Fit \\
\hline
\end{tabular}




\begin{tabular}{|l|c|l|l|}
\hline Goodness of Index & \multicolumn{1}{|c|}{ Cut-Off Value } & Hasil Model & Keterangan \\
\hline PNFI & $0,60-0,90$ & 0,654 & Good Fit \\
\hline
\end{tabular}

\section{Sumber: hasil perhitungan AMOS}

Setelah terlihat model Goodness of Fit diatas dengan hasil secara keseluruhan Good Fit, maka langkah berikutnya adalah pengukuran setiap konstruk untuk menilai unidimensionalitas dan reliabilitas dari konstruk. Nilai construct reliability (CR) akan dianggap baik apabila memberikan nilai $\geq 0,70$ dan variance extracted (VE) akan dianggap baik apabila memberikan nilai $\geq 0,50$. Syarat yang harus dipenuhi, pertama loading factor harus signifikan (Ghozali, 2014). Oleh karena standard loading masih dapat menghasilkan angka yang kurang dari 0,50, maka indikator tersebut dapat dieliminasi. Setelah dilakukannya eliminasi terhadap faktor tersebut, maka hasil penilaian tersebut dapat dilihat melalui Tabel 3, dengan hasil yang menunjukkan reliabilitas dan validitas yang baik.

Tabel 4. Pengukuran Construct Reliability dan Variance Extracted

\begin{tabular}{|c|c|c|c|c|}
\hline \multirow[b]{2}{*}{ Items } & \multirow{2}{*}{$\begin{array}{l}\text { Validitas } \\
\text { Standard } \\
\text { Loading }\end{array}$} & \multicolumn{2}{|c|}{ Reliabilitas } & \multirow[b]{2}{*}{ Keterangan } \\
\hline & & $\begin{array}{l}\text { Construct } \\
\text { Reliability }\end{array}$ & $\begin{array}{c}\text { Variance } \\
\text { Extracted }\end{array}$ & \\
\hline Tekanan & & 0,812 & 0,709 & Reliabilitas Baik \\
\hline $\mathrm{T} 1$ & Deleted & & & - \\
\hline $\mathrm{T} 2$ & Deleted & & & - \\
\hline T3 & Deleted & & & - \\
\hline $\mathrm{T} 4$ & 0,784 & & & Validitas Baik \\
\hline T5 & 0,699 & & & Validitas Baik \\
\hline T6 & Deleted & & & - \\
\hline Kesempatan & & 0,800 & 0,667 & Reliabilitas Baik \\
\hline KES1 & Deleted & & & - \\
\hline KES2 & 0,810 & & & Validitas Baik \\
\hline KES3 & 0,823 & & & Validitas Baik \\
\hline KES4 & Deleted & & & - \\
\hline KES5 & Deleted & & & - \\
\hline Rasionalisasi & & 0,786 & 0,556 & Reliabilitas Baik \\
\hline R1 & Deleted & & & - \\
\hline R2 & 0,726 & & & Validitas Baik \\
\hline R3 & 0,808 & & & Validitas Baik \\
\hline R4 & 0,690 & & & Validitas Baik \\
\hline $\mathrm{R} 5$ & Deleted & & & - \\
\hline Kemampuan & & 0,861 & 0,563 & Reliabilitas Baik \\
\hline KEM1 & Deleted & & & - \\
\hline KEM2 & Deleted & & & - \\
\hline KEM3 & 0,663 & & & Validitas Baik \\
\hline KEM4 & 0,850 & & & Validitas Baik \\
\hline KEM5 & 0,826 & & & Validitas Baik \\
\hline KEM6 & 0,638 & & & Validitas Baik \\
\hline $\begin{array}{l}\text { Kecurangan } \\
\text { Akademik }\end{array}$ & & 0,776 & 0,637 & Reliabilitas Baik \\
\hline KA1 & Deleted & & & - \\
\hline KA2 & Deleted & & & \\
\hline
\end{tabular}




\begin{tabular}{|l|l|l|l|l|}
\hline \multirow{3}{*}{ Items } & \multicolumn{1}{|c|}{ Validitas } & \multicolumn{2}{|c|}{ Reliabilitas } & \multirow{2}{*}{ Keterangan } \\
\cline { 2 - 4 } & $\begin{array}{c}\text { Standard } \\
\text { Loading }\end{array}$ & $\begin{array}{c}\text { Construct } \\
\text { Reliability }\end{array}$ & $\begin{array}{c}\text { Variance } \\
\text { Extracted }\end{array}$ & \\
\hline KA3 & Deleted & & & - \\
\hline KA4 & 0,708 & & & Validitas Baik \\
\hline KA5 & 0,879 & & & Validitas Baik \\
\hline
\end{tabular}

Sumber: hasil perhitungan AMOS

\subsection{Temuan}

Gambar 2 berikut menunjukkan hasil output dari path diagram atas model penelitian.

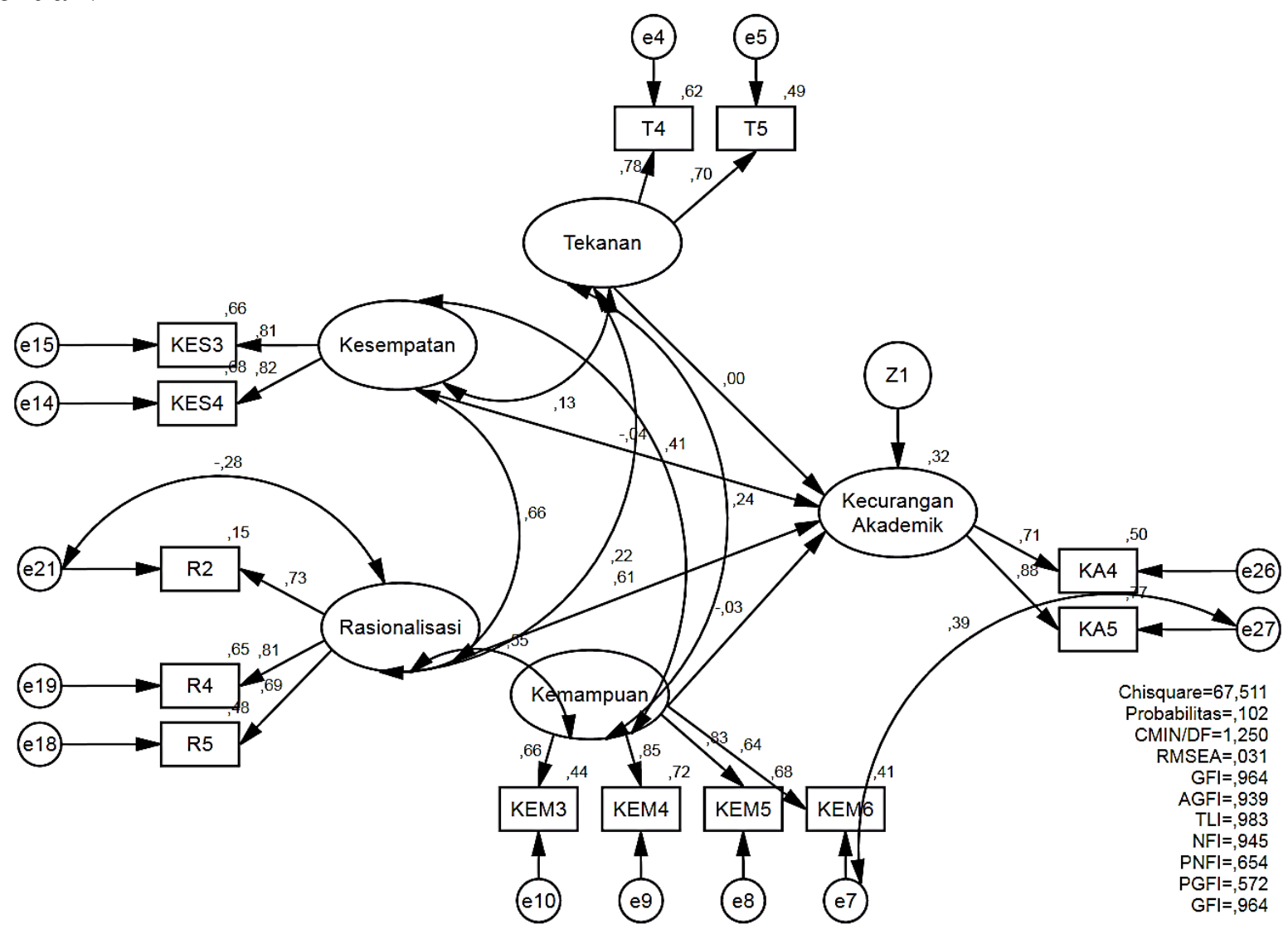

Sumber: data yang diolah

Gambar 2. Path Diagram dari Perilaku Kecurangan Akademik Mahasiswa Accounting

Sedangkan tabel 4 berikut menunjukkan hasil pengujian atas model struktural.

Tabel 4. Hasil Pengujian Model Struktural

\begin{tabular}{|c|c|c|c|c|}
\hline Hipotesis & Hubungan antar Konstruk & Path Coefficient & $p$-value & Keterangan \\
\hline $\mathrm{H}_{1}$ & Tekanan $\rightarrow$ Kecurangan Akademik & 0,00 & 0,995 & Rejected \\
\hline $\mathrm{H}_{2}$ & $\begin{array}{l}\text { Kesempatan } \rightarrow \text { Kecurangan } \\
\text { Akademik }\end{array}$ & $-0,04$ & 0,742 & Rejected \\
\hline $\mathrm{H}_{3}$ & $\begin{array}{l}\text { Rasionalisasi } \rightarrow \text { Kecurangan } \\
\text { Akademik }\end{array}$ & 0,61 & $\begin{array}{l}* * * \\
\text { (kurang }\end{array}$ & Accepted \\
\hline
\end{tabular}




\begin{tabular}{|l|l|l|l|l|}
\hline Hipotesis & \multicolumn{1}{|c|}{ Hubungan antar Konstruk } & Path Coefficient & p-value & Keterangan \\
\hline $\mathrm{H}_{4}$ & $\begin{array}{l}\text { Kemampuan } \rightarrow \text { Kecurangan } \\
\text { Akademik }\end{array}$ & $-0,03$ & 0,720 & Rejected \\
\hline
\end{tabular}

\section{Sumber: hasil perhitungan AMOS}

Pada model diatas, hubungan antara tekanan terhadap kecurangan akademik adalah berpengaruh positif dan tidak signifikan (dengan p sebesar 0,995 dan koefisien sebesar 0,00). Oleh karena itu, hipotesis satu ditolak yang berarti bahwa faktor tekanan yang dirasakan tidak memiliki pengaruh terhadap perilaku kecurangan akademik mahasiswa Universitas XYZ.

Selanjutnya hubungan pada kesempatan terhadap kecurangan akademik adalah berpengaruh negatif dan tidak signifikan (dengan p sebesar 0,742 dan koefisien sebesar -0,04). Hal ini menunjukkan bahwa tidak adanya pengaruh dari faktor kesempatan yang dirasakan terhadap perilaku kecurangan akademik, sehingga hipotesis dua ditolak.

Hasil pengujian selanjutnya adalah antara rasionalisasi terhadap kecurangan akademik, yang terbukti berpengaruh positif dan signifikan (dengan p yang disimbolkan *** atau memiliki arti kurang dari 0,01 dan koefisien sebesar 0,61). Hasil ini mengindikasikan bahwa adanya pengaruh rasionalisasi yang dirasakan terhadap tindak kecurangan akademik mahasiswa, sehingga hipotesis tiga diterima.

Hasil terakhir yaitu antara kemampuan dengan kecurangan akademik, yang terbukti berpengaruh negatif dan tidak signifikan (dengan $p$ sebesar 0,720 dan koefisien sebesar -0,03). Hasil ini menunjukkan bahwa hipotesis empat ditolak karena kemampuan yang dimiliki terbukti tidak berpengaruh terhadap perilaku kecurangan akademik yang dilakukan oleh mahasiswa.

\subsection{Diskusi}

Penelitian ini mengaplikasikan model fraud diamond (Wolfe \& Hermanson, 2004) untuk memprediksi keempat faktor yang mempengaruhi tindak kecurangan akademik mahasiswa. Pada penelitian ini faktor tekanan yang dirasakan oleh mahasiswa Universitas XYZ tidak memiliki pengaruh terhadap perilaku kecurangan akademik, sehingga hipotesis pertama ditolak. Hasil ini bertolak belakang dengan temuan peneliti sebelumnya yaitu Becker et al., (2006) yang menyatakan bahwa tekanan dari luar yaitu orang tua, teman sebaya, hingga komite beasiswa dan tekanan dari dalam seperti tingkat kesulitan dan banyaknya tugas yang diberikan oleh dosen, mempengaruhi mahasiswa untuk melakukan kecurangan. Murdiansyah \& Sudarma (2017) juga mengemukakan bahwa tekanan seperti demi kelancaran studi, keinginan untuk meningkatkan IPK, banyaknya kegiatan di luar perkuliahan, dan paksaan dari teman, mempengaruhi tindakan kecurangan yang dilakukan mahasiswa. Munirah \& Nurkhin (2018) menemukan bahwa tekanan eksternal (kemampuan orang tua, durasi ujian, tingkat kesulitan soal ujian, serta tuntutan dari orang tua) dan internal (pemahaman materi ujian), cenderung mendorong tindak kecurangan akademik. Begitu juga dengan Muhsin et al., (2018) yang mengindikasikan adanya pengaruh tekanan terhadap kecurangan akademik. Namun, hasil ini konsisten dengan penelitian Budiman (2018) yang mengatakan bahwa mahasiswa tidak merasa tertekan atau terbebani oleh hal terkait perkuliahan, sehingga mereka tidak perlu berbuat curang. 
Begitu pula pada penelitian Hariri et al., (2018) dan Sabli et al., (2018), yang mengemukakan bahwa tekanan tidak memiliki pengaruh terhadap tindak kecurangan akademik. Sehingga penelitian ini tidak dapat membuktikan teori fraud diamond yang dikemukakan oleh Wolfe dan Hermanson (2004) maupun teori fraud triangle oleh Cressey (1953), yang menyatakan bahwa tekanan mempengaruhi perilaku kecurangan. Indikator-indikator yang menjadi acuan penelitian ini pada variabel tekanan adalah ekspektasi orang tua atau keluarga untuk mendapatkan nilai yang tinggi dan rasa tidak senang jika nilainya dibandingkan dengan orang lain, terbukti tidak mendorong mahasiswa untuk melakukan kecurangan. Sehingga dapat disimpulkan bahwa mahasiswa akuntansi Universitas XYZ tidak memiliki tekanan dari orang tua untuk mendapatkan nilai yang baik, maupun tertekan apabila nilainya dibandingkan dengan orang lain.

Variabel selanjutnya adalah kesempatan. Hubungan antara kesempatan dengan kecurangan akademik terbukti memiliki hubungan yang negatif dan tidak signifikan. Hasil ini bertolak belakang dengan beberapa penelitian terdahulu seperti Becker et al., (2006) yang menjelaskan bahwa kesempatan yaitu dosen yang kurang tegas, keadaan kelas, sistem ujian yang monoton, dan perkembangan alat komunikasi menjadi penyebab kecurangan akademik. Murdiansyah \& Sudarma (2017) serta Munirah \& Nurkhin (2018) pun mengatakan bahwa lemahnya pengawasan selama ujian merupakan pendorong mahasiswa untuk melakukan tindakan kecurangan akademik. Begitu pula dengan penelitian Muhsin et al., (2018) yang mengemukakan bahwa kesempatan mempengaruhi tindak kecurangan akademik mahasiswa. Namun hasil ini sesuai dengan penelitian Budiman (2018) yang menyatakan bahwa mahasiswa tidak merasa adanya kesempatan untuk berbuat curang karena adanya pengawasan yang ketat saat ujian, ketegasan sanksi, dan mahasiswa tidak dapat memilih sendiri kursi saat ujian. Begitu juga dengan penelitian Nurkhin et al., (2018), yang menyatakan bahwa mahasiswa tidak akan melakukan kecurangan walaupun dosen pengawas tidak melakukan pengawasan dengan baik. Oleh karena itu penelitian ini tidak dapat membuktikan teori Fraud Diamond yang dikemukakan oleh Wolfe dan Hermanson (2004) maupun teori Fraud Triangle oleh Cressey (1953), yang menyatakan bahwa kesempatan dapat mempengaruhi perilaku kecurangan. Indikator-indikator yang menjadi acuan penelitian ini dalam variabel kesempatan adalah lemahnya pengawasan selama ujian dan dosen jarang menyadari adanya tindak kecurangan, terbukti tidak mendorong mahasiswa untuk melakukan kecurangan. Oleh karena itu dapat disimpulkan bahwa pengawasan ujian dan kesadaran dosen akan tindak kecurangan pada Universitas XYZ sudah sangat baik sehingga mahasiswa tidak memiliki kesempatan untuk melakukan perilaku kecurangan.

Variabel selanjutnya adalah rasionalisasi. Hubungan antara variabel rasionalisasi dengan kecurangan akademik terbukti memiliki pengaruh yang positif dan signifikan. Hasil yang positif ini konsisten dengan beberapa penelitian sebelumnya yaitu Becker et al., (2006), yang mengemukakan adanya pengaruh dari rasionalisasi terhadap kecurangan akademik seperti keyakinan bahwa nantinya dosen tidak akan menyadari kecurangan yang dilakukan. Murdiansyah \& Sudarma (2017) pun menemukan bahwa 
kecurangan akademik dipengaruhi oleh faktor rasionalisasi terutama saat mahasiswa merasa bahwa hal yang dilakukannya biasa dilakukan oleh orang lain, sehingga Ia juga boleh melakukan hal tersebut. Hasil serupa juga ditemukan oleh Muhsin et al., (2018) dan Munirah \& Nurkhin, (2018) yang menyatakan bahwa perilaku kecurangan akademik oleh mahasiswa dipengaruhi oleh tindakan rasionalisasi. Hal ini menggambarkan bahwa faktor yang paling mendorong mahasiswa Universitas XYZ untuk melakukan kecurangan akademik merupakan faktor rasionalisasi yang dirasakan oleh para mahasiswa. Berdasarkan hasil tersebut, penelitian ini dapat membuktikan teori fraud diamond yang dikemukakan oleh Wolfe dan Hermanson (2004) serta teori fraud triangle oleh Cressey (1953), yang menyatakan bahwa tindakan untuk merasionalisasi merupakan penyebab perilaku kecurangan. Indikator-indikator yang menjadi acuan penelitian ini dalam menentukan variabel rasionalisasi yaitu merasa tindak kecurangan yang dilakukan tidak merugikan orang lain, hal yang biasa dilakukan, dan banyak mahasiswa yang mencontek. Sehingga dapat disimpulkan mahasiswa akuntansi Universitas XYZ terbiasa melakukan kecurangan karena adanya tindak untuk merasionalisasi seperti merasa tidak merugikan orang lain, hal tersebut biasa dilakukan, dan banyak mahasiswa lain yang mencontek.

Variabel terakhir adalah kemampuan. Hubungan kemampuan terhadap kecurangan akademik terbukti memiliki pengaruh yang negatif namun tidak signifikan. Hasil yang ditemukan ini bertolak belakang dengan penelitian Hariri et al., (2018) yang mengemukakan kemampuan merupakan sikap berhati-hati dan melakukan pendekatan kepada dosen dapat mendorong tindak kecurangan akademik. Munirah \& Nurkhin (2018), menyimpulkan bahwa kemampuan untuk menekan rasa bersalah dapat mempengaruhi mahasiswa untuk melakukan kecurangan akademik. Begitu juga Artani \& Wetra (2017) serta Sabli et al., (2018) yang menemukan korelasi positif signifikan antara variabel kecurangan akademik dan kemampuan. Namun hasil ini sesuai dengan penelitian Nurkhin (2018), yang menyatakan bahwa mahasiswa dengan kemampuan lebih cenderung tidak melakukan tindak kecurangan. Mahasiswa yang dapat mengontrol diri lebih baik akan menghindari perbuatan yang curang, baik saat mengerjakan tugas maupun ujian. Begitu juga dengan Muhsin et al., (2015) yang menemukan bahwa mahasiswa tidak akan melakukan kecurangan meskipun mereka memiliki kemampuan untuk melakukannya. Sehingga penelitian ini tidak dapat membuktikan teori fraud diamond yang dikemukakan oleh Wolfe dan Hermanson (2004), yang menyatakan bahwa faktor kemampuan dapat mempengaruhi perilaku kecurangan. Indikator-indikator yang menjadi acuan penelitian ini pada variabel kemampuan adalah merasa sangat yakin bahwa tindakan yang dilakukan tidak akan diketahui orang lain (ego), mampu meyakinkan orang lain agar tidak melaporkan tindakan tersebut (coercion), mampu membuat berbagai alasan untuk menutupi tindakan kecurangan (deceit), dan mampu menekan rasa bersalah (stress), terbukti tidak mendorong mahasiswa untuk melakukan tindakan kecurangan. Sehingga dapat disimpulkan bahwa mahasiswa akuntansi Universitas XYZ tidak memiliki kemampuan untuk merasa yakin bahwa tindakannya tidak akan terdeteksi, meyakinkan orang lain 
agar tidak melaporkan perilakunya, membuat berbagai alasan untuk menutupi perbuatannya, dan menekan rasa bersalah.

\section{PENUTUP}

\subsection{Kesimpulan}

Setelah melakukan penelitian atas topik "Kecurangan Akademik pada Mahasiswa Akuntansi Berdasarkan Perspektif Fraud Diamond" dengan mengacu pada (Sabli et al., 2018), dapat diindikasikan bahwa para mahasiswa akuntansi dari Universitas XYZ hanya terdorong oleh faktor rasionalisasi untuk melakukan tindak kecurangan akademik. Mahasiswa universitas XYZ tidak memiliki tekanan dari orang tua untuk mendapatkan nilai yang baik, maupun tertekan apabila nilainya dibandingkan dengan orang lain. Pengawasan ujian dan kesadaran dosen akan tindak kecurangan pada Universitas XYZ sudah sangat baik sehingga mahasiswa tidak memiliki kesempatan untuk melakukan kecurangan. Mahasiswa akuntansi Universitas XYZ juga tidak memiliki kemampuan untuk merasa yakin bahwa tindakannya tidak akan terdeteksi, meyakinkan orang lain agar tidak melaporkan perilakunya, membuat berbagai alasan untuk menutupi perbuatannya, dan menekan rasa bersalah. Hasil berikut berbeda dengan beberapa penelitian sebelumnya, sehingga dapat dikatakan bahwa mahasiswa akuntansi dari Universitas XYZ melakukan tindak kecurangan akademik bukan karena tertekan, memiliki kesempatan, ataupun memiliki kemampuan untuk melakukan tindakan tersebut.

\subsection{Implikasi}

Penelitian berikut turut memberikan manfaat teoritis melalui Fraud Diamond theory yang memiliki keterkaitan dengan tindak kecurangan akademik. Hasil penelitian berkontribusi terutama kepada lembaga pendidikan agar dapat melakukan tindakan preventif maupun menanggulangi masalah kecurangan akademik setelah mengetahui faktor-faktor yang dapat menyebabkan perilaku tersebut, agar kedepannya para calon akuntan dapat memiliki integritas dan kompeten dalam menjalankan perannya dimasyarakat.

Setelah mengetahui bahwa rasionalisasi merupakan faktor pendorong utama mahasiswa akuntansi untuk melakukan tindak kecurangan akademik, maka dapat memberikan beberapa masukan bagi Universitas XYZ terutama prodi Accounting seperti pembekalan lebih mendalam terkait perilaku kecurangan akademik saat dilaksanakannya program orientasi studi dan memberikan pembekalan nilai-nilai kampus secara tepat. Kemudian disarankan kepada seluruh faculty member untuk memberikan sosialisasi mengenai sanksi yang akan dikenakan kepada para mahasiswa seperti yang tertulis pada silabus setiap memulai ajaran baru, sehingga dapat menyadarkan mahasiswa bahwa tindakan tersebut tidak dapat ditoleransi pada Universitas XYZ. Peraturan yang ditegakkan pun harus terefleksi dengan jelas, sehingga apabila para mahasiswa ada yang ketahuan melakukan tindak kecurangan akademik, maka apapun yang terjadi peringatan pertama tetap harus dijalankan, baik itu untuk tugas, kuis, maupun ujian. Selain itu kedepannya diharapkan kepada Universitas XYZ untuk meningkatkan kontrol di setiap kelas, seperti contoh memasang CCTV atau 
security camera untuk menghindari adanya tindak kecurangan akademik atau menjadi bukti apabila perilaku tersebut terjadi. Kelima, diharapkan kepada Universitas XYZ untuk dapat memiliki kode etik pada mahasiswa sehingga para mahasiswa tersebut tidak dapat merasionalkan tindak kecurangan yang dilakukannya.

\subsection{Keterbatasan Penelitian}

Dalam penelitian berikut terdapat beberapa keterbatasan saat melakukan penelitian. Pertama, penelitian berikut hanya berasal pada satu lingkup universitas swasta, dengan jurusan akuntansi saja sehingga tidak dapat mencerminkan bahwa mahasiswa universitas lain atau jurusan lain juga akan terdorong oleh faktor pendorong kecurangan akademik yang sama pula. Kedua, responden berasal dari salah satu universitas ternama di kota besar, para mahasiswa pun sudah cukup menyadari bahwa menyontek bukanlah perilaku yang baik sehingga mereka berusaha tidak melakukan tindakan tersebut. Hal berikut tercermin melalui kuesioner Kecurangan Akademik dengan hasil menunjukkan rata-rata mahasiswa melakukan tindakan menyontek hanya sesekali atau pada skala likert kedua. Atas hasil tersebut, dapat dikatakan bahwa mahasiswa akuntansi tersebut sudah memiliki integritas yang cukup baik. Ketiga, pada kuesioner bagian kedua penelitian berikut tidak memaparkan pemilihan waktu yang spesifik atau jelas, seperti frekuensi yang tepat sasaran pada "sesekali", "jarang", "sering", dan "selalu" sehingga tidak dapat terukur mengenai acuan frekuensi kecurangan akademik yang dilakukan oleh para mahasiswa Prodi S1 Akuntansi Universitas XYZ. Keempat, penelitian berikut tidak memasukkan faktor "waktu" pada variabel tekanan, yang jika faktor tersebut dimasukkan maka variabel pendukung tekanan pun dapat meningkat. Hal berikut tercermin ketika para mahasiswa memiliki rentang waktu yang cukup singkat untuk menyelesaikan seluruh tugas yang diberikan oleh faculty member, diikuti dengan jadwal kuis atau ujian yang berdekatan.

\subsection{Saran}

Melalui keterbatasan penelitian yang telah dipaparkan diatas, maka dapat diberikan beberapa saran. Pertama, penelitian selanjutnya disarankan untuk menggunakan sampel yang lebih luas, misalkan dengan mengkombinasikan dengan jurusan lain sehingga tercermin perilaku kecurangan akademik secara lebih luas. Kedua, penelitian selanjutnya disarankan menambahkan variabel independen lain yang tidak dijelaskan pada penelitian berikut, sehingga dapat diteliti faktor-faktor lain penyebab perilaku kecurangan akademik. Ketiga, penelitian selanjutnya disarankan untuk memaparkan rentang atas frekuensi perilaku kecurangan akademik secara jelas, sehingga tidak terdapat ambiguitas pada responden ketika mengisi "sesekali", "jarang", "sering", dan "selalu". Hal berikut dapat memberikan persepsi yang sama kepada seluruh responden maupun pembaca dari penelitian yang sedang dilakukan.

\section{DAFTAR PUSTAKA}

Artani, K. T. B., \& Wetra, I. W. (2017). Pengaruh Academic Self Efficacy dan Fraud Diamond Terhadap Perilaku Kecurangan Akademik Mahasiswa Akuntansi di 
Bali. Jurnal Riset Akuntansi (JUARA), 7(2), 123-132. Retrieved from http://jurnal.unmas.ac.id/index.php/JUARA/article/viewFile/856/787

Azuka, E. B. (2014). Academic Fraud among Students in Higher Education in Nigeria: Reasons, Methods Adopted and Strategies to Curb It. Journal of Educational and Social Research. Retrieved from https://doi.org/10.5901/jesr.2014.v4n3p289

Becker, D., Connolly, J., Lentz, P., \& Morrison, J. (2006). Using The Business Fraud Triangle To Predict Academic Dishonesty Among Business Students. 10(1), 18. Retrieved from https://www.questia.com/library/journal/1G1166778518/using-the-business-fraud-triangle-to-predict-academic

Budiman, N. A. (2018). Perilaku Kecurangan Akademik Mahasiswa: Dimensi Fraud Diamond dan Gone Theory. Akuntabilitas, 11(1). Retrieved from https://doi.org/10.15408/akt.v11i1.8135

Chapman, K. J., \& Lupton, R. A. (2004). Academic dishonesty in a global educational market: a comparison of Hong Kong and American university business students. International Journal of Educational Management, 18(7), 425-435. Retrieved from https://doi.org/10.1108/09513540410563130

Dahiya, R. (2015). Academic cheating among students: pressure of parents and teachers, $5 . \quad$ Retrieved from http://www.allresearchjournal.com/archives/2015/vol1 issue10/PartL/1-102.pdf

Davis, S. F., Grover, C. A., Becker, A. H., \& McGregor, L. N. (1992). Academic Dishonesty: Prevalence, Determinants, Techniques, and Punishments. Teaching of Psychology, 19(1), 16-20. Retrieved from https://doi.org/10.1207/s15328023top1901_3

Ellahi, A., Mushtaq, R., \& Bashir Khan, M. (2013). Multi campus investigation of academic dishonesty in higher education of Pakistan. International Journal of Educational Management, 27(6), 647-666. Retrieved from https://doi.org/10.1108/IJEM-03-2012-0039

Ghozali, Imam. (2014). Model Persamaan Struktural Konsep dan Aplikasi dengan Program AMOS 22 Update Bayesian SEM. Semarang: BP UNDIP.

Hariri, H., Pradana, A. W. S., \& Rahman, F. (2018). Mendeteksi Perilaku Kecurangan Akademik Dengan Perspektif Fraud Diamond Theory. Retrieved from https://www.neliti.com/publications/269668/mendeteksi-perilaku-kecuranganakademik-dengan-perspektif-fraud-diamond-theory

Hariyanto, W., Rini, D. D. O., \& Margianawati, D. (2015). Pengaruh Dimensi Fraud Diamond Terhadap Perilaku Kecurangan Akademik Mahasiswa Akuntansi Yang Dimoderasi Religiusitas, $16 . \quad$ Retrieved from https://publikasiilmiah.ums.ac.id/handle/11617/10327

Ismail, S., \& Yussof, S. H. (2016). Cheating behaviour among accounting students: some Malaysian evidence. Accounting Research Journal, 29(1), 20-33. Retrieved from https://doi.org/10.1108/ARJ-05-2014-0050 
Muhsin, M., Kardoyo, K., \& Nurkhin, A. (2018). What Determinants of Academic Fraud Behavior? From Fraud Triangle to Fraud Pentagon Perspective. KnE Social Sciences, 3(10), 154. Retrieved from https://doi.org/10.18502/kss.v3i10.3126

Munirah, A., \& Nurkhin, A. (2018). Pengaruh Faktor-Faktor Fraud Diamond dan Gone Theory Terhadap Kecurangan Akademik, 20. Retrieved from https://journal.unnes.ac.id/sju/index.php/eeaj/article/view/22862

Murdiansyah, I., \& Sudarma, M. (2017). Pengaruh Dimensi Fraud Diamond Terhadap Perilaku Kecurangan Akademik (Studi Empiris pada Mahasiswa Magister Akuntansi Universitas Brawijaya). Jurnal Akuntansi Aktual, 4(2), 13. Retrieved from http://journal.um.ac.id/index.php/jaa/article/view/9814/4648

Nurkhin, A. (2018). Analisis Pengaruh Dimensi Fraud Diamond Terhadap Perilaku Kecurangan Akademik Mahasiswa Pendidikan Akuntansi Unnes, 1, 12. Retrieved from http://jurnal.umsu.ac.id/index.php/LIAB/article/view/2026

Sabli, N., Hamid, N. A., Haron, N. H., \& Wahab, R. A. (2018). Academic Cheating Among Undergraduate Accounting Students: Fraud Diamond Theory Perspective, $6 . \quad$ Retrieved from http://jrhnamsca.icu/index.php/hnamsca/article/view/527

Wolfe, D. T., \& Hermanson, D. R. (2004). The Fraud Diamond: Considering the Four Elements of Fraud, 6. 6 Retrieved from https://pdfs.semanticscholar.org/c9c8/32fa299f648464cbd0172ff293f5c35684 b6.pdf 